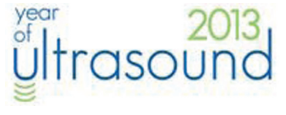

\title{
ultrasound 世first:
}

\section{EUROSON 2013, Stuttgart}

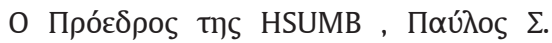

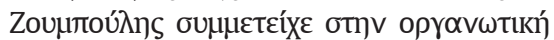

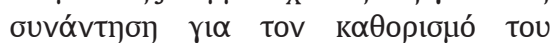

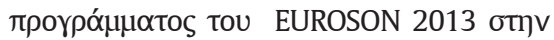

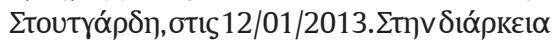

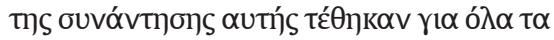

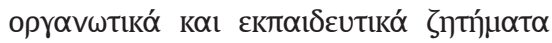

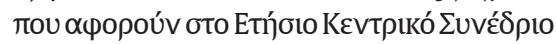
TnS EFSUMB. 